\title{
KÉPZÉSI HÁTTÉR ÉS GYERMEKVÁLLALÁSI TERVEK
}

\author{
VEROSZTA ZSUZSANNA - GYÖRGYI ZOLTÁN* \\ ${ }^{a}$ Központi Statisztikai Hivatal, Népességtudományi Kutatóintézet \\ Beérkezett: 2021. április 6., elfogadva: 2021. június 13.
}

A tanulmány a népesedési folyamatok és az oktatási rendszer kölcsönhatásának értelmezési keretében mozog. Ezen belül a szülői végzettség egy lehetséges demográfiai következményével, a második gyermek vállalásának tervezésére gyakorolt hatásával foglalkozik. Az elemzés a KSH NKI Kohorsz '18 Magyar Születési Kohorszvizsgálat várandósok körében gyüjtött adatain alapul. Az eredmények alapján az anyák második gyermek vállalására vonatkozó terveiben mindkét szülő végzettségének önálló hatása mutatható ki. A szülői iskolázottság szintje és a második gyermek tervezése között pozitív a kapcsolat. Legerősebb a felsőfokú végzettség hatása, mely mindkét szülő esetében növeli a második gyermek tervezésének esélyét. A szakképzettség alacsony szinten csökkenti, ugyanakkor a magasabb, középfok feletti szinteken növeli a gyermekvállalási kedvet. Az anyai tervekre az apa legmagasabb iskolai végzettsége is kimutatható hatással bír. Az eredmények oktatáspolitikai szempontú értelmezésében kiemelhető a magasabb végzettségi szintek gyermekvállalásra gyakorolt pozitív hatása, valamint a szakmunkásképzés felé irányítás potenciálisan kedvezőtlen demográfiai következményeinek azonosítása.

Kulcsszavakः oktatáspolitika, népesedés, társadalmi rétegek és az oktatás

The interpretive framework of the study is the interaction between demographic trends and the education system. Within this, it addresses a possible demographic consequence of parental education, i.e., its impact on the planning of having a second child. The analysis is based on the data of Cohort '18 Growing Up In Hungary, collected among pregnant women by the Hungarian Demographic Research Institute in 2018 as a part of a Hungarian Birth Cohort Study. According to the results, the plans of the expecting mothers to have a second child significantly affected by the educational attainment. As regards directions, there is a linear positive relationship between the level of education and the odds of planning a second child. Higher educational background of both parents shows the strongest effect on the plans. Elementary vocational training works against planning chances, but upper vocational background increases the desire to have a second child. Educational attainment of the partner also has a significant effect on maternal childbearing plans. From the point of view of educational policy, the positive effect of higher education degree on having children can be highlighted. Potentially unfavor-

* Levelező szerző: Györgyi Zoltán, E-mail: gyorgyiz@ella.hu 
able demographic consequences of the direction towards vocational training can be also highlighted by the results.

Keywords: education policy, demography, social structure and education

\section{Előszó}

A tanulmány célja a képzettség gyermekvállalási tervekre gyakorolt hatásának azonosítása egy szűkített demográfiai szituációban: az újabb gyermekvállalás tervezése az első gyermekkel már várandós anyák körében. A tágabb, elméleti orientációjú célunk a népesedési és oktatáspolitikai szempontok elemző összekapcsolása. Ennek során a családtervezési döntést képzési keretbe ágyazzuk be, azt vizsgálva, hogy mely anyai, avagy szülői végzettségi konstrukciók növelik leginkább a második gyermek vállalásának esélyét, illetve - oktatáskutatási nézőpontból - milyen oktatáspolitikai döntések, oktatási rendszerben zajló folyamatok alakítják ezeket a végzettségi trendeket. A végzettség mérése, azonosítása során a demográfiai orientációjú kutatásokban bevett egyszerűsített hierarchikus változó helyett az oktatáskutatásban alkalmazott többitemes, a szakképzés és felsőfokú képzés heterogenitását képviselö változóval dolgoztunk. Ez a finomabb képzési háttérváltozó jobban megragadhatóvá teszi a hazai képzési rendszer és az azt alakító szakpolitika sajátosságait. Elemzésünk során a végzettség és a gyermekvállalási tervek közötti kapcsolat feltárásán túl célunk oksági kapcsolat azonosítása is. Az anyai és szülői képzettségi szint második gyermek vállalásának tervezésére gyakorolt hatását ezért a családtervezés egyéb, a demográfiai szakirodalomban már igazolt hatótényezőinek leválasztásával mutatjuk ki, miközben a képzettségi szint esetében a statisztikai magyarázóerőt oktatáskutatási elemzéssel, szakpolitikai folyamatok elemzésével értelmezzük. Vizsgálatunk eredményeként lényegében tehát a végzettségi szintet meghatározó oktatási rendszerfolyamatok és oktatáspolitikai döntések egy lehetséges demográfiai hatását - a gyermekvállalás alakulását - kívánjuk bemutatni.

\section{A gyermekvállalási trendek}

Az utóbbi évek gyermekvállalási tendenciája az élveszületések számának 90 ezer születés körüli stagnálása (2020-ban 92233, 2019-ben 89193 gyermek született a KSH Élveszületési statisztikája alapján). 100 ezer feletti születésszámot utoljára 1997-ben rögzítettek. A népesség ezer lakosra vetített természetes fogyása 1980 óta folyamatos (www. ksh.hu/stadat). A teljes termékenységi arányszám növekszik ugyan (értéke 2019-ben 1,49), de nem éri el a népesség pótlásához szükséges újratermelést jelentő 2-es értéket. A KSH által közölt tisztított reprodukciós együttható értéke 2019-ben 0,715 volt (www. ksh.hu/stadat).

Az európai trendbe egyébként illeszkedő adatok mögött a szülőképes korú nők alacsony létszáma áll, miközben a tervezett gyermekszám alapvetően stabil maradt (Kapitány-Murinkó 2020). A gyermekvállalás esélye némileg kétpólusú mintát követ: a gyermektelenek és egygyermekesek aránya, valamint a nagycsaládossá (3+ gyermek) válás esélye egyaránt növekszik, s a kétgyermekes családok aránya van csökkenőben (Németh 
2016; Kapitány-Spéder 2018). E családmodell aránycsökkenése 2011 után főleg a középfokú és szakmunkás végzettségüek esetében jelentkezett - körükben az egy gyermeket nevelő családok aránya nőtt. A legalább három gyermek vállalásának gyakorisága a legalacsonyabb végzettségi csoportokban nőtt jelentősen (Harcsa-Monostori 2018). A termékenységi görbe életkori megoszlásán bimodális (kétcsúcsú) mintázat mutatható ki, mely paritásspecifikusan az első és második gyermekvállalást tekintve különösen hangsúlyos (Kapitány 2018). Eszerint a gyermekvállalási kedv 2011 után tapasztalt növekedése (vö. termékenységnövekedés) főleg a legfiatalabb (-20) és az idősebb (30+) szülőképes nők életkori csoportját jellemzi. A huszonéves nők esetében a növekedés bár érzékelhető, átlag alatti maradt (Kapitány-Murinkó 2020). A gyermekvállalás tervezésének másik életkori összefüggése az a rendszerváltást követően azonosított halasztó hatás, amely egyes társadalmi-demográfiai csoportok esetében egyre későbbre tolja ki a termékenységi életpálya elindítását (Spéder-Kapitány 2007). A folyamat mögött egyfelől az átlagéletkor növekedése, a szülőképes kor kitolódása áll, másfelől az időközben lezajlott képzési expanzió és a nők fokozódó munkába állása. Az anyák esetében a magasabb végzettség megszerzésének vagy a kedvezőbb munkaerőpiaci státusz elérésének egyaránt halasztó hatása lehet. A magasabb végzettségü nők esetében az életkori kitolódás azonban később gyakrabban jár nagyobb gyermekvállalási hajlandósággal (Takács 2012).

A gyermekvállalás tervezésére ható párkapcsolati hatásként értelmezhető trend, hogy miközben az élettársi kapcsolatban élő párok házasságban élőkhöz viszonyított aránya dinamikusan nőtt, addig a gyermekvállalás tervezése (Spéder-Kapitány 2007) és e tervek megvalósulása egyaránt a házasságban élő nők esetében nagyobb esélyü (Spéder-Kapitány 2009). Az együtt élö partner nélkül gyermeket vállaló anyák aránya továbbra is alacsony. A partnerkapcsolati helyzet és gyermekvállalás közti kapcsolatot mindemellett életkori és végzettségi háttértényezők is dominálják: így például a házasságban élők esetében későbbre tolódik a gyermekvállalás, a diplomás nők többnyire házasságban vállalnak gyermeket, míg az alacsonyabb végzettségü anyák esetében mind az élettársi kapcsolat, mind az együtt élő partner nélküli gyermekvállalás gyakoribb (Kapitány-Murinkó 2020).

A gazdasági-munkaerőpiaci folyamatok gyermekvállalásra gyakorolt hatásának vizsgálatai szerint önmagában a növekvő női foglalkoztatottság esetében nem igazolható direkt negativ hatás a termékenységre. A folyamat ennél jóval heterogénebb, s ezt az összetett munkavállalási hatást jóléti programok, szociális támogatások és ellátások, a munkavállalási szabályok átalakítása egyaránt igyekszik csökkenteni, különböző sikerességgel (Gábos 2008). A harmadik gyermek vállalásának esetében például bebizonyosodott az állami beavatkozás pozitív hatása, ám amíg az alacsonyabb végzettségüek esetében a gyermekgondozási időszak kitolása, addig a magas végzettségüek esetében az adókedvezmény volt a releváns termékenységi motiváló faktor (Spéder-Murinkó-Oláb 2017, 2019). A családtámogatási rendszer közvetlen pénzbeni ellátásai esetében pozitív termékenységi hatás mutatkozik (Gábos 2008). A családpolitika az állami gyermeknevelési támogatások összességét (közvetett és közvetlen formáit) magába foglalva hozzájárulhat a termékenység növekedéséhez (Gábos-Gál-Kézdi 2009).

A női munkavállalás felfutása egyúttal a munka és a magánélet összehangolásának problémáival, a háztartási munkaterhek egyenlőtlen elosztásával is járhat. A nők terhei e szempontból a gyermekvállalással többnyire nagyobb arányban növekednek (Takács 2012). Úgy tűnik, hogy a gyermekvállalás külső korlátainak leginkább a középszintű végzettségűek vannak kitéve. Az állami támogató háttér, az óvodai, bölcsődei ellátáshoz való 
hozzáférés szűkössége és a munkaerőpiac kedvezőtlenebb körülményei, bizonytalansága is állhatnak e csoport alacsonyabb termékenysége mögött (Spéder 2006). Az állami családtámogatási rendszer szolgáltatásának tekinthető a gyerekek napközbeni ellátásának intézményi biztosítása is, melynek hatása közvetlenül a női munkavállalás, hosszabb távon a termékenység, gyermekvállalás alakulásában azonosítható (Blaskó 2009). Ebből a szempontból meghatározó tényező a bölcsődei korosztály számára rendelkezésre álló helyek szűkös volta (Makay-Blaskó 2012), a kisgyermekes anyák munkavállalásának, s ezzel összefüggésben a bölcsődei ellátás igénybevételének kedvezőtlen társadalmi megítélése (Makay 2018) és a szolgáltatás kapcsolata az anyai igényekkel (Kapitány 2020). A női munkaerőpiaci státusz esetében a gyermekvállalási tervek kapcsán (az aktuálisan anyasági ellátáson lévő nők magas tervezési szándékán túl) jól látszik, hogy az inaktív státusz, azaz a munkanélküliség, álláskeresés, tanulói státusz negatívan hat a rövid távú gyermekvállalás szándékára, időbeni kitolódási hatásként ugyanakkor a későbbre vonatkozó terveket megemeli (Spéder-Kapitány 2007).

A gyermekvállalás közgazdasági meghatározóit tekintve a tiszta jövedelmi hatás a kedvezőbb anyagi körülmények között (magasabb háztartási jövedelmi szinten) élők nagyobb termékenységi esélyeit eredményezheti. Ezt az összefüggést azonban több közgazdasági tényező árnyalja. Befolyással van rá az aktuális gazdasági helyzet, melynek következtében a munkaerőpiacra történő belépés esélyének romlása-javulása ellenkezőképpen érinti a foglalkoztatott és munkanélküli (inaktív) nők gyermektervezési döntéseit (Spéder 2001; Husz 2006). De ilyen befolyásoló tényező a kedvezőbb jövedelmi-iskolázottsági szinten lévők gyermekvállaláshoz kapcsolódó magasabb elvárási szintje, tehát a gyermek megfelelő felnevelésének nagyobb becsült költsége (Spéder 2001; Bartus 2017). E gyermekvállalási költségek igen tág kört ölelhetnek fel (lásd erről Gábos-Gál-Keller 2007), és képezhetik további kalkulációk, modellek alapját. Ilyen, a gyerekvállalási döntésekre ható tényezők komplex modellje Németh (2016) mikroszintü, dinamikus életciklus-modellezése, amely a gyermekvállalással járó költségek széles körét veszi figyelembe, beépítve mindazon környezeti, intézményi, szociálpolitikai, munkaerőpiaci tényezőket, melyek a családok egyéni döntésére hatnak.

A magyarországi, rendszerváltás utáni gyermekvállalási döntéseket meghatározó tényezők áttekintése után a tervezettséget és a tervek beválásának alakulását is érdemes lehet figyelembe venni. Spéder és Kapitány (2014) összegzése alapján Liefbroer (2009) a gyermekvállalási terveket és azok megvalósulását az életút kontextusában értelmező átfogó elmélete szerint a lehetőségek folyamatos átstrukturálódása a gyermekvállalási tervek időbeni csökkenésével jár. Ebbe az irányba hatnak a házasságon kívüli párkapcsolatok, a hosszabb munkaerőpiaci elöélet, a magasabb végzettségi szint is (Liefbroer 2009, idézi Spéder-Kapitány 2014). Maga a gyermekvállalás tervezése, tervezettsége különösen fontossá válik egy, a tervezett gyermekek születését támogató, a jelenlegi hazai családpolitikát is jellemző népesedéspolitika kontextusában. Ezek a beavatkozások ugyanis az előzetes döntésen, tervezésen alapuló gyermekvállalást feltételezik és erre építve kínálják támogató intézkedéseiket. A nem tervezett gyermekek születésére ezen típusú csomagok és politikák inkább közvetetten hathatnak csak (Kapitány-Murinkó 2020). Magyar kutatási adatok szerint ugyanakkor a tervezettség hazai mértéke relatíve alacsony: 2018ban a várt gyermekek 6,4 százalékát nem tervezték a szülők, további egyötödük a tervezettnél korábban fogant (ilyen értelemben időben még nem tervezett gyermekvállalásról van szó) (Kapitány-Murinkó 2020). 


\section{Végzettség és családtervezés}

A végzettség és gyermekvállalás kapcsolatának főbb trendjeit összegezve Spéder (2019) kiemeli a gyermekvállalási magatartás rendszerváltást követő növekvő társadalmi státuszmeghatározottságát. Az iskolai végzettségre lefordítva mindezt, a legkevesebb változást az alacsony (alapfokú) végzettségűek gyermekvállalási mintázata mutat, következetesen magas, korai anyai életkorhoz köthető gyermekszámával. A szakmunkás végzettség esetében lecsökkent gyermekvállalási mutatókat találunk, melyek életkor tekintetében szélesen szórnak. Az érettségizettek szintén csökkenő gyermekvállalási kedve már az életkor későbbre tolódásával is együtt jár. A felsőfokú végzettségűek gyermekvállalása úgyszintén halasztott, ám gyerekvállalási mutatói jelentősen növekvőek (Spéder 2019; Kapitány-Spéder 2018).

$\mathrm{A} z$ anyai iskolai végzettségre épülő termékenységet magyarázó modellek mellett a szülői végzettségi kombináció figyelembevétele is fontos szempont lehet. A trendek nemzetközi összevetésben is a végzettség alapú párkapcsolati homogámia felé mutatnak, melyhez a képzési expanzió, a nők növekvő képzettségi szintje megfelelő muníciót is biztosít (Erát 2021). A partnerszelekciós döntések mögötti, a származási hatásokhoz képesti erősebb teljesítménymeghatározottság a társadalmi átalakulások következménye, melynek során az egyének helyzete is nagyobb mértékben függ elért jellemzőitől, szerzett erőforrásaitól, mint öröklött státuszától (Bukodi 2005). A képzés szerinti házassági homogámia főként a két legnagyobb mértékben növekvő végzettségi csoport a legalacsonyabb és legmagasabb végzettségűek - körében összpontosul (Bukodi 2001). A párkapcsolati végzettségi homogámia szempontjából tekintve az elemzés alapjául is szolgáló 2018-as év statisztikai adataira azt találjuk, hogy mind az öt anyai végzettségi kategóriában az anyával azonos végzettségü apa esetében volt a legmagasabb az élveszületések száma (az 1. táblázatban kurziválással kiemelve). A 2018-ban született majd 9 ezer gyermek esetében a leggyakoribb szülői végzettségi kategória a két felsőfokú végzettségű szülőé volt. A második leggyakoribb a két középfokú végzettségű szülő. Ezt követte két heterogám párkapcsolati mintázat gyakorisága, mindkét esetben a diplomás vagy középfokú végzettségű anyához képest egy szinttel alacsonyabb végzettségi szintü apákról van szó (1. táblázat). Mindez természetesen ez esetben nem a gyermekvállalási szándékok egyenlőtlen megoszlására utal, mindössze a szülöpár végzettségi szintjének gyakori összekapcsolódását mutatja - előrevetítve, hogy a párkapcsolati képzettségi

1. táblázat: Az élveszületések száma Magyarországon a szülők iskolai végzettsége szerint, 2018-ban

\begin{tabular}{llc}
\hline $\begin{array}{l}\text { Az anya legmagasabb iskolai } \\
\text { végzettsége }\end{array}$ & \multicolumn{1}{c}{$\begin{array}{l}\text { Az apa legmagasabb iskolai } \\
\text { végzettsége }\end{array}$} & $\begin{array}{c}\text { Az élveszületések } \\
\text { száma (fö) }\end{array}$ \\
\hline Általános iskola 0-7. osztálya & Általános iskola 0-7. osztálya & 131 \\
& $\begin{array}{l}\text { Befejezett általános iskola (8. osztály) } \\
\text { Befejezett szakmunkásképző iskola, }\end{array}$ & 418 \\
& szakiskola & 92 \\
& Befejezett középiskola & 23 \\
& Befejezett felsőfokú iskola & n. a. \\
& Ismeretlen & 1042 \\
\hline
\end{tabular}


1. táblázat: (folyt.)

\begin{tabular}{|c|c|c|}
\hline $\begin{array}{l}\text { Az anya legmagasabb iskolai } \\
\text { végzettsége }\end{array}$ & $\begin{array}{l}\text { Az apa legmagasabb iskolai } \\
\text { végzettsége }\end{array}$ & $\begin{array}{l}\text { Az élveszületések } \\
\text { száma (fö) }\end{array}$ \\
\hline \multirow[t]{6}{*}{ Befejezett általános iskola (8. osztály) } & Általános iskola $0-7$. osztálya & 258 \\
\hline & Befejezett általános iskola (8. osztály) & 6005 \\
\hline & $\begin{array}{l}\text { Befejezett szakmunkásképző iskola, } \\
\text { szakiskola }\end{array}$ & 2770 \\
\hline & Befejezett középiskola & 1224 \\
\hline & Befejezett felsőfokú iskola & 82 \\
\hline & Ismeretlen & 5557 \\
\hline \multirow{6}{*}{$\begin{array}{l}\text { Befejezett szakmunkásképző iskola, } \\
\text { szakiskola }\end{array}$} & Általános iskola $0-7$. osztálya & 37 \\
\hline & Befejezett általános iskola (8. osztály) & 1361 \\
\hline & $\begin{array}{l}\text { Befejezett szakmunkásképzö iskola, } \\
\text { szakiskola }\end{array}$ & 5217 \\
\hline & Befejezett középiskola & 2002 \\
\hline & Befejezett felsőfokú iskola & 288 \\
\hline & Ismeretlen & 1173 \\
\hline \multirow[t]{6}{*}{ Befejezett középiskola } & Általános iskola $0-7$. osztálya & 9 \\
\hline & Befejezett általános iskola (8. osztály) & 1832 \\
\hline & $\begin{array}{l}\text { Befejezett szakmunkásképző iskola, } \\
\text { szakiskola }\end{array}$ & 7281 \\
\hline & Befejezett középiskola & 14561 \\
\hline & Befejezett felsőfokú iskola & 4212 \\
\hline & Ismeretlen & 1483 \\
\hline \multirow[t]{6}{*}{ Befejezett felsőfokú iskola } & Általános iskola $0-7$. osztálya & \\
\hline & Befejezett általános iskola (8. osztály) & 257 \\
\hline & $\begin{array}{l}\text { Befejezett szakmunkásképző iskola, } \\
\text { szakiskola }\end{array}$ & 2373 \\
\hline & Befejezett középiskola & 8544 \\
\hline & Befejezett felsöfokú iskola & 18372 \\
\hline & Ismeretlen & 469 \\
\hline \multirow[t]{6}{*}{ Ismeretlen } & Általános iskola 0-7. osztálya & \\
\hline & Befejezett általános iskola (8. osztály) & 11 \\
\hline & $\begin{array}{l}\text { Befejezett szakmunkásképző iskola, } \\
\text { szakiskola }\end{array}$ & 7 \\
\hline & Befejezett középiskola & 7 \\
\hline & Befejezett felsőfokú iskola & 12 \\
\hline & Ismeretlen & 2696 \\
\hline Összesen & & 89806 \\
\hline
\end{tabular}

Forrás: KSH Élveszületési Statisztika, 2018, saját szerkesztés 
homogámia-heterogámia szempontja vizsgálatra érdemes a gyermekvállalási tervek vonatkozásában is.

A gyermekvállalási magatartás képzési háttérjellemzőinek fentebb bemutatott, aszimmetrikus $U$ alakú görbével illusztrált jellemzői tehát az alacsonyabb és magasabb képzettségi szintek nagyobb, a középfokú végzettek, s különösen a szakmunkások alacsonyabb termékenységét mutatják (Kapitány 2018). Az emögött meghúzódó oktatási rendszerfolyamatokat vizsgálva Husz (2006) részletesen foglalkozik a képzési expanzió esetleges termékenységcsökkentő hatásával. Magyarázata szerint - jóllehet a fokozottabb tanulási kedv mögött értékváltozási hatások is állnak - a termékenység domináns meghatározóját, a munkaerőpiaci bizonytalanságot épp a magasabb végzettség elérése tudja csökkenteni, mely azonban a gyermekvállalási időszak kitolódásával járhat. $\mathrm{A} z \mathrm{U}$ alakú végzettségi-termékenységi görbe azonban arra utal, hogy a kulturális hatások, az értékátrendeződés következtében a gyermekvállalás időzítésének iskolázottság szerinti különbségei nőttek jelentősen, mely egyben a magasabb végzettség és a társadalmi szülőképes kor kitolódását is jelenti (Husz 2006).

A második gyerek megszületésének esélyére vonatkozó vizsgálatában Bartus és munkatársai szintén a fenti látszólagos ellentmondást, a nők végzettségiszint-emelkedésének pozitív termékenységi hatását vizsgálták. E közgazdasági elméletek alapján a várttól (iskolázottsági szinttel növekvő gyermeknevelési költségek, kieső jövedelem és karrierkockázatok) eltérő trend mögött három lehetséges hatást feltételeztek: az önszelekciós hatás, az időpréshatás és a partnerhatás szerepét tesztelték. Előbbi a magasabban végzett nők eleve nagyobb gyermekvállalási szándékát feltételezi. Az időpréshatás a képzésben való részvétellel bekövetkezett halasztás miatti gyorsabb második gyermekvállalásra épít a termékeny kor elörehaladtával. A partnerhatás-hipotézis pedig a magasabb végzettségủ nők képzettebb, ezáltal gazdaságilag jobb helyzetü partnereinek jövedelmi hatásként realizálódó pozitív termékenységi hatására épít. Mindezeket figyelembe véve (kontrollálva) a képzési szint emelkedése és a második gyermek időben közelebbi vállalásának esélye közötti pozitív kapcsolat feltárása során a szerzők a végzettségi szint önálló oksági hatását azonosították (Bartus et al. 2013). Ezt a második gyermek vállalására vonatkozó tiszta végzettségi hatást az időprés- és partnerhatás kontrollálásával Bartus 2017-es tanulmányában longitudinális adatok elemzésével ismét kimutatta, igazolva az anyai képzettségi szint U alakú termékenységi görbe mögötti magyarázó erejét (Bartus 2017).

\section{Kutatási kérdések}

A fent azonosított összefüggések és előzmények alapján az oktatási rendszer és a demográfiai folyamatok - azon belül a gyermekvállalási tervek - kapcsolatát első gyermeküket váró anyák körében felvett adatokon (lásd lent) az alábbi kutatási kérdések mentén vizsgáljuk.

a) Összefügg-e az anyai, illetve szülői végzettségi szint a 2. gyermek vállalásának tervével (első gyermeket váró anyák és párok körében)?

b) Összefüggés esetén milyen irányú és mely szinteken érvényesülő kapcsolat azonosítható?

c) Összefüggés esetén a kapcsolat oksági, avagy közvetett? Tehát egyéb tényezők kontrollálása után is fennáll-e? 
d) A képzési rendszerben bekövetkezett és lehetséges/tervezett beavatkozások mindezek alapján hová mozdíthatják a gyermekvállalási szándékot?

Összességében: melyek lehetnek az egyes oktatáspolitikai döntések lehetséges demográfiai következményei, különös tekintettel a gyermekvállalás elősegítésére mint központi népesedéspolitikai szándékra?

\section{Adatok és módszer}

Az elemzés a KSH Népességtudományi Kutatóintézet Kohorsz '18 Magyar Születési Kohorszvizsgálat ${ }^{1}$ címen zajló születési kohorszvizsgálatának első, várandósok körében felvett adatain alapul. A longitudinális kutatási program első adatfelvételi hullámára 2018-ban és 2019 tavaszán került sor, az ekkor 7. várandóssági hónapot töltő anyák 10 százalékos országos reprezentatív mintáján (Veroszta 2018). A 8287 válaszadó adatait személyes lekérdezés során saját körzeti védőnőjük rögzítette. A kutatási adatbázis reprezentativitását súlyozási eljárással az anya életkorára, családi állapotára, gyermekei számára, iskolai végzettségére és lakóhelyére biztosították (Szabó et al. 2020).

A kutatási kérdések megválaszolásához a kiinduló adatbázist leszükítettük az első gyermeküket váró anyák almintájára $(n=3855)$. Ennek következtében a paritás szempontjából homogén csoporton vizsgáltuk a további gyermekvállalási terveket (melyek így kizárólag a második gyermek vállalására szükültek) és az erre ható képzési tényezőket.

A vizsgálat alapját képező kimeneti változó a második gyermek vállalásának szándéka a demográfiai kutatásokban a rövid távú tervezést jelentő három éven belül, az anyák tervei alapján. A kutatás adatai szerint összességében az első gyermeküket váró anyák közel kétharmada, 63 százaléka tervezi, hogy első gyermeke megszületése után három éven belül újabb gyermeket is vállal.

Az elemzés végzettségi háttérváltozóiként egyfelől az anyai képzettséget, másfelől az apa anyához viszonyított végzettségi szintjét alkalmazzuk. Az anya legmagasabb iskolai végzettségét tekintve a vizsgálat egy, a bevett kategorizációnál részletesebb bontást alkalmaz annak érdekében, hogy az egyes végzettségi szinteken - szakképzés, közép-, ill. felsőfokú végzettségek - belüli eltéréseket is elemezzük. A minta végzettség szerinti megoszlását a 2. táblázat tartalmazza.

A vizsgálat másik képzettségi magyarázó változója az apa képzettségi szintjét is beépíti, s végzettségi szintjét az anyáéhoz viszonyítva veszi figyelembe. A szülőpárok közti képzettségi homogámia-heterogámia változójának kialakítása során az anya négy itemre kódolt végzettségéhez (alapfok/szakmunkásképzés/középfok/felsőfok) viszonyítottuk $a z$ apa végzettségét. $A z$ apa iskolázottságára vonatkozó adatok az anyai válaszokon alapulnak. Eszerint az első gyermeket váró - és partnerrel rendelkező - nők több mint fele (mintegy 55 százaléka) a végzettséget tekintve homogám párkapcsolatban él. Többnyire, az anyák 23 százaléka esetén két felsőfokú végzettségü szülöről van szó. A párok 16 százalékánál az apa végzettsége magasabb, mint az anyáé, a fennmaradó kb. 30 százalék esetében pedig az apai végzettség az alacsonyabb. A heterogám végzettségi formák közül

A kutatás finanszírozására az EFOP-1.9.4-VEKOP-16-2016-00001 A szociális ágazat módszertani és információs rendszereinek megújítása c. operatív program keretei között került sor. Megvalósítója a KSH Népességtudományi Kutatóintézet. 
2, táblázat: A várandós anyák legmagasabb iskolai végzettsége az első gyermeküket váró anyák körében

\begin{tabular}{lcc}
\hline & $n$ & $\%$ \\
\hline Max. 8 általános & 587 & 15,2 \\
Szakmunkásképző; szakképzés érettségi nélkül & 405 & 10,5 \\
Szakközépiskolai érettségi; szakképzést követő érettségi & 464 & 12,0 \\
Gimnáziumi érettségi & 428 & 11,1 \\
Érettségit követő, felsőfokra nem akkreditált szakképzés; középfokú technikum & 558 & 14,5 \\
Akkreditált felsőfokú szakképzés; felsőfokú technikum & 212 & 5,5 \\
Főiskola, BA/BSc szint & 636 & 16,5 \\
Egyetem, MA/MSc szint, osztatlan képzés, doktorátus & 564 & 14,6 \\
\hline Összesen & 3854 & 100,0 \\
\hline
\end{tabular}

Forrás: KSH NKI Kohorsz'18 kutatás, várandós adatfelvétel, 2019

a leggyakoribb (14,7 százalék) a diplomás anya és az alacsonyabb végzettségü partner előfordulása (3. táblázat).

3. táblázat: Várandós anya és partnere legmagasabb iskolai végzettsége az első gyermeküket váró, partnerrel rendelkező anyák körében

\begin{tabular}{lrr}
\hline & $n$ & $\%$ \\
\hline Anya-apa alapfok & 276 & 7,4 \\
Anya alapfok / apa magasabb & 252 & 6,7 \\
Anya szakmunkás / apa alacsonyabb & 65 & 1,7 \\
Anya-apa szakmunkás & 205 & 5,5 \\
Anya szakmunkás / apa magasabb & 115 & 3,1 \\
Anya középfok / apa alacsonyabb & 498 & 13,3 \\
Anya-apa középfok & 685 & 18,3 \\
Anya középfok / apa magasabb & 234 & 6,3 \\
Anya felsőfok / apa alacsonyabb & 547 & 14,7 \\
Anya-apa felsőfok & 858 & 23,0 \\
\hline Összesen & 3735 & 100,0 \\
\hline
\end{tabular}

Forrás: KSH NKI Kohorsz'18 kutatás, várandós adatfelvétel, 2019

A szülői végzettségi szint gyermekvállalásra gyakorolt hatásának vizsgálatát további háttérváltozók bevonásával bővítettük annak érdekében, hogy a tervezésre ható, ezen egyéb tényezők hatását elkülöníthessük, kontrollálhassuk a képzési hatások azonosítása során. Az ennek érdekében alkalmazott változók a párkapcsolati státusz (házas, avagy nem házas szülők), az anyai inaktivitás, avagy foglalkoztatottság (a foglalkoztatott státuszba beleértve a várandósság vizsgált időszakát már táppénzen töltő anyákat is), 
az anyai életkor (3-as bontásban), valamint az ekvivalens háztartás-jövedelmi kvintilisek változója. ${ }^{2}$

Az elemzés során első lépésben a fenti háttérváltozók és a második gyermek vállalásának tervezése közötti összefüggéseket khí-négyzet próbákkal vizsgáltuk. Ezt követően két magyarázó modellben, bináris logisztikus regressziós eljárás alkalmazásával azonosítottuk az anyai, illetve a szülői képzési háttér gyermekvállalási tervekre gyakorolt önálló hatását.

\section{A gyermekvállalási tervek és a szociodemográfiai háttér}

$\mathrm{A} z$ első gyermeküket váró anyák körében a további gyermekvállalás aránya az iskolai végzettségi szint növekedésével határozottan emelkedik. A legalacsonyabb ez az arány a 8 általános iskolai osztályt vagy kevesebbet végzett anyák körében. A két érettségi kategória - szakközépiskolai vagy gimnáziumi - végzettjeinek tervei között nincs lényegi különbség. Az alkalmazott végzettségi felosztás alapján a tervezésben az alsóbb

4. táblázat: Gyermekvállalás tervezése három éven belül, az anya iskolai végzettsége szerint az első gyermeküket váró anyák körében

\begin{tabular}{llrll}
\hline $\begin{array}{l}\text { Tervezi, hogy az elkövetkező három éven belül a hamarosan megszületendő gyermeken túl újabb } \\
\text { gyermeket vállal? }\end{array}$ & $\begin{array}{r}\text { Tervezi } \\
n(\text { sor\% })\end{array}$ & $\begin{array}{c}\text { Nem tervezi } \\
n(\text { sor\% })\end{array}$ & Cramer’s $V^{a}$ & Pearson $\chi^{2}$ \\
\cline { 2 - 5 } & $27(34,6)$ & $51(65,4)$ & 0,358 & $460,910^{*}$ \\
\hline Várandós anya legmagasabb iskolai végzettsége $(n=3605)$ & & \\
8 általános alatt & $142(29,9)$ & $333(70,1)$ & $(d f=9)$ & \\
8 általános & $167(44,4)$ & $209(55,6)$ & & \\
Szakmunkásképző; szakképzés & $254(59,6)$ & $172(40,4)$ & & \\
Szakközépiskolai érettségi & $237(59,1)$ & $164(40,9)$ & & \\
Gimnáziumi érettségi & $350(67,4)$ & $169(32,6)$ & & \\
Érettségit követő szakképzés & $144(72,7)$ & $54(27,3)$ & & \\
Akkreditált felsőfokú szakképzés & $464(77,7)$ & $133(22,2)$ & & \\
Főiskola, BA/BSc szint & $427(82,6)$ & $90(17,4)$ & & \\
Egyetem, MA/MSc szint, osztatlan & $15(88,2)$ & $2(11,8)$ & & \\
Tudományos fokozat & $2227(61,8)$ & $1377(38,2)$ & & \\
\hline Összesen & &
\end{tabular}

${ }^{*} p=0,001$

Forrás: KSH NKI Kohorsz'18 kutatás, várandós adatfelvétel, 2019

2 Utóbbi változó bázisa az adatfelvétel önkitöltős kérdőívmoduljában az anya által a háztartás elmúlt havi nettó jövedelmeként zárt vagy nyitott kérdésben megadott érték. A változó létrehozására a tisztított havi háztartási jövedelem folytonos változó értékeiből és a háztartásnagyság változójából került sor. Azok esetén, akik csak kategoriális háztartási jövedelmet adtak meg, a jövedelmi értéket a kategóriaátlaggal helyettesítettük. Ez esetben tehát nem az egyén (anya) hanem a család jövedelmi helyzetével dolgozunk. A változó értékeit a nem válaszolók kategóriájával is kiegészítettük az esetszám megtartása érdekében. 
és magasabb képzési szintek között az érettségi vizsga jelenti a fó választóvonalat. A szakképzés hatása érzékelhető, de a képzési szintekhez illeszkedően, fokozatos emelkedésként mutatkozik meg. Az érettséginél alacsonyabb végzettségi kategóriákban a gyerekvállalási tervek gyakoriságnövekedése némileg meredekebbnek mutatkozik. Ez az arány a szakmunkás végzettségű anyák körében sem éri el az 50 százalékot. Jelentősebb, 60 százalékot elérő ugrás a középfokú végzettségü, nagyszámú anyánál mutatkozik, ezt követően pedig az érettséginél magasabb végzettségek felé egyre nő a második gyermeket tervezők aránya. Ez a növekedés még a felsőfokú végzettségeken belül is tisztán érzékelhető: az alapképzésben és a mesterképzésben végzett (nagyszámú) anyák között 5 százalékpontos a további gyermekvállalási tervek gyakoriságemelkedése.

$\mathrm{A} z$ anya végzettségi szintjéhez viszonyított együttes szülői iskolázottság esetében hasonló növekedési tendenciát látunk a tervek kapcsán. Ez esetben az anyai végzettséget négy kategóriára vontuk össze, az apai iskolázottságot pedig ennek viszonylatában építettük be az itemsorba. Az előző adatsorhoz hasonlóan itt is azt tapasztaljuk, hogy a második gyermek tervezése következetesen növekszik. Látszik az is, ahogy az apa iskolai végzettsége megemeli az anya terveinek gyakoriságát. A két alapfokú végzettségű szülőkhöz képest az ennél magasabb végzettségű apa, de alapfokú végzettségü anya esetén egyharmad feletti a második gyermek tervezésének aránya (ez a nyolc általános végzettségü anyák között összességében a 30 százalékot sem érte el, lásd fent). A szakmunkás végzettségek esetében hasonló a kép. Ha a szakmunkás anya mellett magasabb végzettségü apa van, az jelentősen (8 százalékponttal) növeli az újabb gyermekvállalás tervezésének

5. táblázat: Gyermekvállalás tervezése három éven belül, a szülők iskolai végzettsége szerint az első gyermeküket váró, partnerrel rendelkező anyák körében

\begin{tabular}{|c|c|c|c|c|}
\hline & $\begin{array}{c}\text { Tervezi } \\
n(\text { sor } \%)\end{array}$ & $\begin{array}{c}\text { Nem tervezi } \\
n(\text { sor } \%)\end{array}$ & Cramer's $V^{a}$ & Pearson $\chi^{2}$ \\
\hline \multicolumn{5}{|c|}{ Várandós anya és partnere legmagasabb iskolai végzettsége $(n=3490)$} \\
\hline Anya-apa alapfok & $77(29,8)$ & $181(70,2)$ & 0,299 & $423,173^{*}$ \\
\hline Anya alapfok / apa magasabb & $88(37,3)$ & $148(62,7)$ & $(d f=9)$ & \\
\hline Anya szakmunkás / apa alacsonyabb & $24(39,3)$ & $37(60,7)$ & & \\
\hline Anya-apa szakmunkás & $83(44,1)$ & $105(55,9)$ & & \\
\hline Anya szakmunkás / apa magasabb & $56(51,9)$ & $52(48,1)$ & & \\
\hline Anya középfok / apa alacsonyabb & $267(57,9)$ & $194(42,1)$ & & \\
\hline Anya-apa középfok & $402(63,5)$ & $231(36,5)$ & & \\
\hline Anya középfok / apa magasabb & $163(73,8)$ & $58(26,2)$ & & \\
\hline Anya felsőfok / apa alacsonyabb & $372(72,1)$ & $144(27,9)$ & & \\
\hline Anya-apa felsőfok & $677(83,8)$ & $131(16,2)$ & & \\
\hline Összesen & $2209(63,3)$ & $1281(36,7)$ & & \\
\hline
\end{tabular}

${ }^{*} p=0,001$

Forrás: KSH NKI Kohorsz'18 kutatás, várandós adatfelvétel, 2019 
esélyét. Az ennél alacsonyabb apai végzettség azonban 5 százalékpontos csökkenéssel jár az anyai tervekben. A mintázat közép-és felsőfokon is ugyanez. Az apa képzettségének az anyai tervekre gyakorolt hatását mutatja, hogy nagyobb eséllyel tervez második gyermeket az a középfokú végzettségü anya, akinek diplomás párja van, mint egy diplomás anya, alacsonyabb végzettségü partnerrel. A legnagyobb arányú további gyermekvállalási szándék a szülői végzettségi táblában is egyértelműen a felsőfokú végzettséghez kapcsolódik. Jóllehet bármelyik szülő diplomája növeli a második gyermekvállalás tervezésének gyakoriságát, ez az arány két diplomás szülő esetében kiugróan magas.

$\mathrm{A} z$ iskolai végzettség gyermekvállalási tervekre gyakorolt önálló hatásának azonosítása során alkalmazott magyarázó modellben több, e tervekkel kapcsolatot mutató háttérváltozó hatásának leválasztására törekszünk. Előzetes szakirodalmi elemzésünk alapján az anya párkapcsolati helyzete, anyagi háttere, foglakoztatási helyzete és életkora mind olyan tényezők, melyek befolyásolhatják a második gyermek tervezésének esélyét. A párkapcsolati státusz esetében demográfiai stabilizáló hatás feltételezhető, mely alap-

6. táblázat: Gyermekvállalás tervezése három éven belül az első gyermeküket váró anyák körében

Tervezi, hogy az elkövetkező három éven belül a hamarosan megszületendő gyermeken túl újabb gyermeket vállal?

Tervezi Nem tervezi Cramer's $V^{a}$ Pearson $\chi^{2}$

$n($ sor $\%) \quad n($ sor $\%)$

Párkapcsolati helyzet $(n=3506)$

\begin{tabular}{|c|c|c|}
\hline Nem házas & $830(48,5)$ & $883(51,5)$ \\
\hline Házas & $1386(77,3)$ & $407(22,7)$ \\
\hline
\end{tabular}

Ekvivalens háztartás-jövedelmi ötödök $(n=3604)$

$\begin{array}{llll}\text { 1. ötöd (legalacsonyabb) } & 186(39,2) & 288(60,8) & 0,275 \\ \text { 2. ötöd } & 231(49,5) & 236(50,5) & (d f=5) \\ \text { 3. ötöd } & 397(62,5) & 238(37,5) & \\ \text { 4. ötöd } & 549(71,3) & 221(28,7) \\ \text { 5. ötöd (legmagasabb) } & 673(77,1) & 200(22,9) \\ \text { Nem válaszol } & 192(49,6) & 194(50,4)\end{array}$

\begin{tabular}{lrrr}
\hline Foglalkoztatott $(n=3603)$ & & \\
Igen & $1949(68,6)$ & $892(31,4)$ & $264,676^{*}$ \\
Nem & $277(36,4)$ & $485(63,6)$ & \\
\hline
\end{tabular}

Várandós kora $(n=3603)$

\begin{tabular}{|c|c|c|c|c|}
\hline-25 év & $372(37,6)$ & $617(62,4)$ & 0,325 & $379,945^{*}$ \\
\hline 25-34 év & $1552(74,0)$ & $545(26,0)$ & $(d f=2)$ & \\
\hline 35+ év & $302(58,4)$ & $215(41,6)$ & & \\
\hline Összesen $(n=3604)$ & $2227(61,8)$ & $1377(38,2)$ & & \\
\hline
\end{tabular}

Forrás: KSH NKI Kohorsz'18 kutatás, várandós adatfelvétel, 2019 
ján a házasságban élők további gyermekvállalási tervei gyakoribbak, tervezett és vállalt gyermekszámuk magasabb (Spéder-Kapitány 2007, 2009). Az egy före eső háztartási jövedelem esetében egyfajta humántőke-beruházási hatást feltételezve azt várjuk, hogy a jobb anyagi helyzet további gyermekvállalásra ösztönzi a szülőket (Spéder 2001). Az anyai foglalkoztatottság azért került bele a modellekbe, mert a munkaerőpiaci stabilitás mögött ismét feltételezhetünk pozitív hatást a további gyermekek tervezett vállalására (Spéder-Kapitány 2007). Az anyai életkor esetében azt várjuk, hogy a legfiatalabbaknál kitolódik a második gyermek tervezése (halasztási hatás) (Spéder-Kapitány 2007), amely a középső életkori sávban a legvalószínübb. Az idősebb, 35 év feletti várandósok esetében a 3 éven belüli újabb gyermekvállalást az időpréshatás növelheti (Bartus et al. 2013), ám itt az életkori korlátok visszafoghatják a további tervezést.

Kereszttáblás vizsgálataink e kapcsolatok szignifikáns voltát rendre igazolták. A Cramer-féle $V$ érték alapján az összefüggések erősnek mutatkoznak. Azok a várandósok, akik házasságban élnek, nagyobb eséllyel terveznek újabb gyermeket (77\%). A háztartás jövedelmi szintjének emelkedésével szintén nagyobb ez az arány. Az egyes jövedelmi csoportok között alacsonyabb jövedelmek esetén nagyobb a szintekkel növekvő százalékpontos emelkedés a gyerekvállalási tervekben. A várandósságuk időszaka alatt (akár táppénzes állományban) foglalkoztatásban állók kétszer olyan gyakran tervezik a testvér vállalását (68\%), mint az inaktívak. Életkor tekintetében a legfiatalabb (25 év alatti) várandósok szeretnének legkisebb arányban szülni (37\%) ismét, három éven belül. Leginkább a 25-34 év közötti első gyermeket váró anyáknál valószínüsíthető a testvér vállalása (77\%), de még az első gyermeküket 34 évesnél idősebben vállalók között is 58 százalékos arányban vannak azok, akik 3 éven belül újabb gyereket is szeretnének.

\section{A gyermekvállalási tervekre ható tényezők}

A z anyai, illetve szülői iskolai végzettség második gyermek tervezésére gyakorolt önálló hatását két bináris logisztikus modellben vizsgáltuk. A végzettségi hatás azonosítása és leválasztása érdekében több, fentebb bemutatott, végzettséggel is összefüggö, igazolt hatótényezőt kontroll alatt tartottuk. Az első magyarázó modell magyarázó változója az anya 8 itemes végzettségi szintje volt. A második modell a szülőpár végzettsége közti hierarchikus viszony magyarázó erejét vizsgálta. A bevont kontrollváltozók mindkét modellben azonosak voltak: a párkapcsolat státusza, a háztartás jövedelmi szintje, az anya foglalkoztatottsága és életkora. A modellek függő változója szintén egységesen a gyermektervezés bináris változója $(0=$ nem tervezi, $1=$ tervezi). A modellek az anya 3 éven belüli további gyermekvállalási tervre vonatkozó becsléseiként esélyhányados formájában $(\operatorname{Exp} B)$ jelennek meg az alábbiakban.

$\mathrm{Az}$ 1. magyarázó modell magyarázó ereje 22 százalék. A modell esélyhányadosai alapján az anyai végzettség önálló hatása a gimnáziumi érettségit mint referenciakategóriát tekintve a magasabb képzettségi szinteken jellemző. Eszerint az érettségit követő szakképzés 1,3-szorosára növeli a további gyermekvállalásra vonatkozó terveket. A felsőoktatási szakképzésben tanult várandós anyák a gimnáziumban érettségizettekhez képest másfélszeres valószínűséggel terveznek második gyermeket 3 éven belül. A diplomás várandósok körében a további gyermektervezés esélye közel kétszerese a gimnáziumi érettségivel rendelkezőkének - a főiskolai/BA diplomások esetében 1,9; az egyetemi/ MA végzettek esetében 2,1 az esélyhányados. A gimnáziumi érettséginél alacsonyabb 
7. táblázat: Az anyai végzettség hatása 1. modell

\begin{tabular}{|c|c|}
\hline & $\operatorname{Exp}(B)$ \\
\hline Constant & $0,459^{* * *}$ \\
\hline \multicolumn{2}{|l|}{ Iskolai végzettség (ref. gimnáziumi érettségi) } \\
\hline Max. 8 általános & 0,772 \\
\hline Szakmunkásképzés & 0,829 \\
\hline Szakközépiskolai érettségi & 1,217 \\
\hline Érettségit követő, nem felsőfokú szakképzés & $1,353^{*}$ \\
\hline Felsőoktatási szakképzés & $1,536^{*}$ \\
\hline Főiskola, BA/BSc szint & $1,899^{* * *}$ \\
\hline Egyetem, MA/MSc szint, doktorátus & $2,393^{* * *}$ \\
\hline \multicolumn{2}{|l|}{ Párkapcsolati helyzet (ref. nem házas) } \\
\hline Házas & $2,134^{* * *}$ \\
\hline \multicolumn{2}{|l|}{ Háztartás-jövedelmi ötödök (ref. középső) } \\
\hline Nem válaszol & 0,791 \\
\hline 1. ötöd (legalacsonyabb) & 0,828 \\
\hline 2. ötöd & 0,808 \\
\hline 4. ötöd & 1,154 \\
\hline 5. ötöd (legmagasabb) & 1,183 \\
\hline \multicolumn{2}{|l|}{ Foglalkoztatás (ref. nem foglalkoztatott) } \\
\hline Foglalkoztatott & $1,297^{*}$ \\
\hline \multicolumn{2}{|l|}{ Életkor (ref. 34 év feletti) } \\
\hline 25 év alatti & 1,276 \\
\hline 25-34 éves & $2,264^{* * *}$ \\
\hline $\begin{array}{l}n=3629 \\
-2 \mathrm{LL}=3995,568 \\
\text { Pseudo- } R^{2}(\text { Nagelkerke })=0,22 \\
\text { Hosmer and Lemeshow Test Sig.: 0,469 } \\
{ }^{*} p<0,05 ;{ }^{* *} p<0,01 ;{ }^{* * *} p<0,001 \\
\text { Forrás: KSH NKI Kohorsz'18 kutatás, várandó }\end{array}$ & \\
\hline
\end{tabular}

végzettségű anyák esetében ugyanakkor a modellben nem mutatható ki szignifikáns végzettségi hatás a gyermekvállalási tervekre. A kontrollváltozók között a házasság, a foglalkoztatotti helyzet és a 35 év alatti várandós életkor pozitívan hat a 2. gyermek vállalásának esélyére, de a jövedelem nem.

A két szülő (anyáéhoz viszonyított) együttes végzettségének önálló hatását vizsgáló 2. modell magyarázó ereje a fentihez hasonlóan 22 százalékos. Esélyhányadosai a két középfokú végzettségű szülő referenciakategóriájához képest szignifikánsan alacsonyabbak az alapfokú végzettségű anya esetén (akkor is, ha az apa ennél magasabb képzési szinten végzett). Két szakmunkás szülő esetében az érettségizett szülőpárhoz viszonyított esélyhányados szintén igen alacsony, 0,6-os értéket vesz fel. A szignifikáns pozitív 
8. táblázat: A szülői végzettség hatása 2. modell

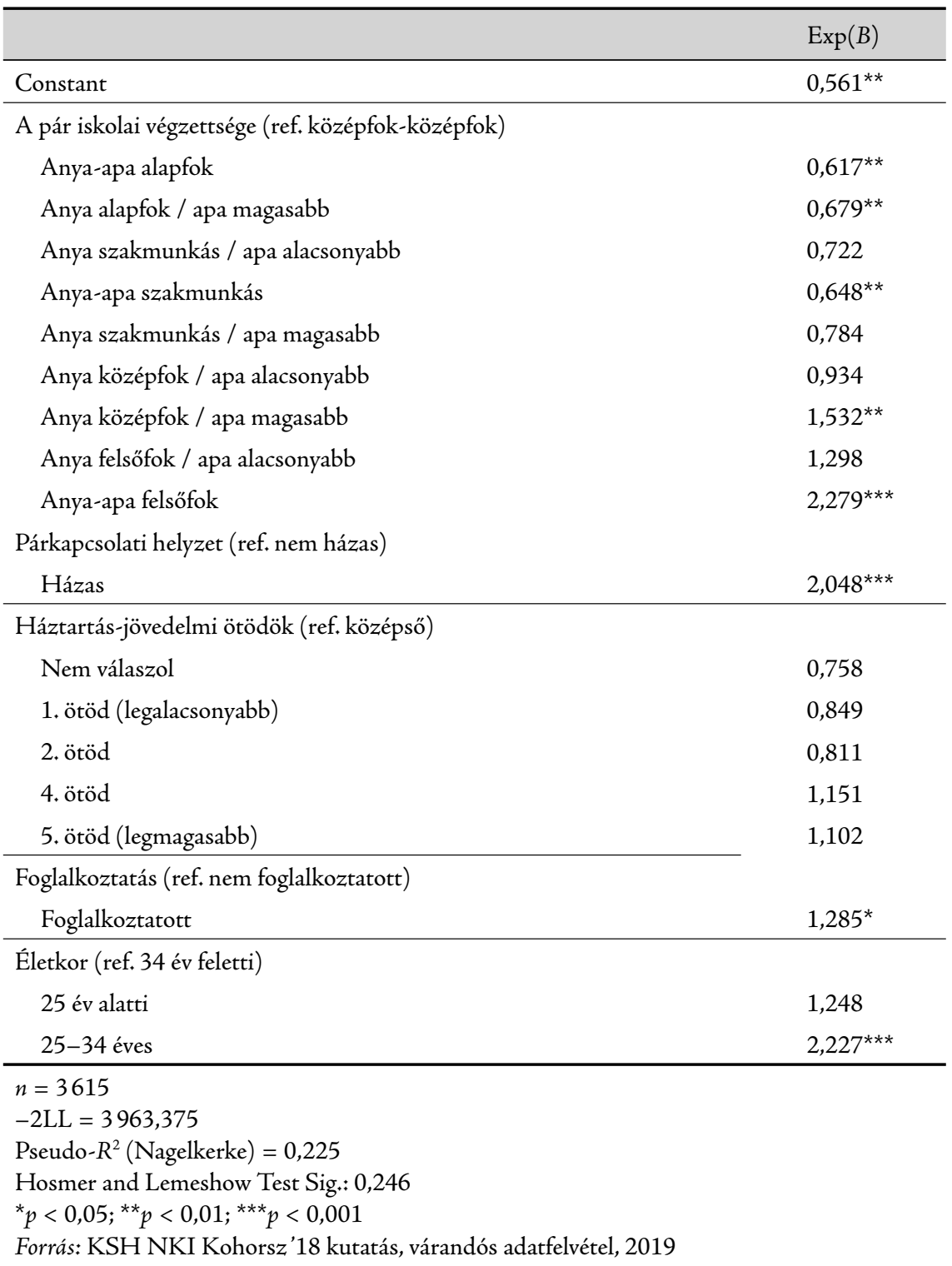

irányú végzettségi hatás a második gyermek tervezésére egyrészt a középfokú anya és felsőfokú apa, másrészt - különösen nagy, 2,3 szoros esélyhányadossal - a két diplomás szülő esetében azonosítható. Az apai végzettség szerepe itt is érdekes: az anya felsőfokú végzettségének nincs hatása a második gyermek tervezésére, ha az apa ennél alacsonyabb végzettséggel bír. Ugyanakkor az apa diplomás volta középfokú anyai végzettség mellett is szignifikáns esélynövelő tényező.

A többváltozós modellek esélyhányadosai azt mutatják, hogy az iskolai végzettségnek mind az anya, mind a szülőpár esetében az egyéb releváns tényezők hatásának kiszűrése 
után is van önálló hatása a második gyermek tervezésére. Az anya végzettségi szintje hierarchikusan és szignifikánsan növeli a tervezés esélyét, de csak az érettséginél magasabb szintű végzettségek esetében. Itt a felsőfokú végzettségen belül is lépcsőzetesen növekvő a hatás. A két szülő végzettségi szintje ugyanakkor az alacsonyabb végzettségek esetében is hat, negatívan befolyásolva a második gyermek tervezését. A szülők esetében a második gyermek tervezésére vonatkozó pozitív hatás az apa felsőfokú végzettsége esetében mutatkozik erősebbnek az anyáéhoz képest. A legerősebb két felsőfokú szülő esetén. Az érettségi feletti szinteken tehát inkább az apai, az alatt inkább az anyai hatás mutatkozik meg. A képzési tekintetben homogám párok esetében minden szinten szignifikáns hatások azonosíthatók. A mindkét szülőt jellemző szakmunkás végzettség jelentősen csökkenti a további gyermekvállalási tervek esélyét. Az eredmények azt is mutatják, hogy míg a megvalósult gyermekvállalás esetében a két szélső végzettségi pólus produkálja a legnagyobb arányokat (termékenységükkel $U$ alakú görbét írva le), addig a tervezés tekintetében a képzési szint szerinti összefüggés lineáris: a magasabb végzettségi szinteken gyakoribb a második gyermeket tervezők aránya.

$\mathrm{A} z$ az eredmény, mely szerint az anyai gyermekvállalási terveket az apák végzettsége (különösen a felső képzési szinteken) kimutathatóan dominálja, a férfiak alacsonyabb átlagos végzettségi szintjének demográfiai hatásaira irányíthat figyelmet, különös tekintettel a szakképzések felé irányításnak mint oktatáspolitikai célnak a születésekre ható járulékos következményére.

\section{Oktatási rendszerkörnyezet: a képzési rendszer folyamatai}

Mivel a népesedési folyamatok és az oktatási rendszer működése, s ennek eredményeként a lakosság iskolázottsága között kölcsönös az összefüggés, a népesedéspolitikának - ha adott térben és időben definiálható ilyen politika - és az oktatáspolitikának is figyelembe kell vennie a másik szakpolitika törekvéseit, várható hatásait. Tanulmányunk - bár az iskolázottság gyermekvállalásra gyakorolt hatását helyezi középpontba - elsődlegesen oktatási térben mozog, így a gyermekvállalás várható változásának oktatást érintő következményeire is ki kell térnünk. Ehhez részben a múlt tapasztalataira utalunk, részben pedig az oktatási keresletet és kínálatot érintő jelenkori folyamatokra. Mivel a hazai családpolitika képviselői gyakran hangoztatják, hogy a tervezett és a ténylegesen megszületett gyerekszám közötti különbséget kívánják csökkenteni, ezért tanulmányunkban kitüntetett szerepet tulajdonítottunk a családokban másodikként tervezett gyermekeknek. Az ezzel kapcsolatos szülői szándékok oktatást érintő következményeit is ezen a szemüvegen keresztül nézzük.

Hogy a gyerekszám növelésére irányuló családpolitika a jövőben milyen eredményt ér el, nem tudjuk. Az utóbbi évtized adatai azt mutatják, hogy az ún. teljes termékenységi arányszám, amely a pillanatnyi adatokból kiindulva azt jelzi, hogy egy nő élete során hány gyermeknek ad életet, a 2011. évi mélypont $(1,23)$ után növekedésnek indult, a 2016. évi tetőzés óta viszont változatlan $(1,49)$. Az élveszületések száma ugyanakkor a 2016. évi lokális maximumot követően folyamatosan csökken (KSH Stadat 22.1.1.1.). Ez pedig azt jelenti, hogy egyelőre nem rajzolódik ki a múlt század hatvanas évek végi, hetvenes évek eleji népességpolitikai intézkedéseinek következményeire vonatkozó párhuzam, amikor is a megnövekedő gyerekszám sok évtizedre kihatóan, generációkon átívelően hatott az oktatási kapacitásokra, hol azok hiányát, hol pedig kihasználatlan- 
ságukat okozva. Ha országos szinten nem is várható ilyen hatás, egyes térségekben a különböző társadalmi rétegek eltérő demográfiai folyamatai következtében járhatnak ilyen következményekkel, tompítva - vagy akár fel is erősítve - a belső migráció oktatást érintő következményeit. Különösen középfokon várható ilyen hatás, mert itt a három hagyományos képzési program iránti igény társadalmi rétegenként eltérő. A következőkben éppen ezért elsősorban a középfokú képzéssel kapcsolatos szakpolitikai törekvéseket és folyamatokat helyezzük előtérbe, nem figyelmen kívül hagyva a felsőfokú oktatás középfokra gyakorolt szívóhatásának kérdését sem. (Nem foglalkozunk viszont a felsőfokú oktatás és a demográfiai folyamatok közötti közvetlen hatással, mert azok bonyolultsága - figyelembe véve, hogy itt már nemzetközi térben kell gondolkodnunk önálló tanulmányt igényelne.)

Az utóbbi három évtized tapasztalatai azt mutatják, hogy a középfokú programok iránti kereslet jelentős mértékben - akár a szakpolitikai törekvések ellenében is - kikényszerítette a kínálat ehhez való igazodását. Függetlenül attól, hogy az utóbbival kapcsolatos döntések milyen irányt képviseltek, s hogy a fenntartói döntések decentralizált vagy centralizált rendszerben születtek. A 2010-es kormányváltás előtti időszak ezt az igazodást kifejezetten támogatta: a fenntartók és maguk az intézmények is érdekeltek voltak a tanulói létszámok megtartásában, növelésében, így a programkínálat tanulói igényekhez igazításában.

A 2010 utáni oktatáspolitika nemcsak az irányítási rendszer centralizálását tűzte ki célul, s valósította is meg néhány év alatt, hanem folyamatosan hangsúlyozza a szakképzés jelentőségét a középfokú oktatásban ${ }^{3}$, nem beszélve arról, hogy a szakképzés irányítási és müködési rendszerének többszöri átalakítása is a középfokú szakképzés fontosságát helyezte előtérbe. A célt két - egymást nem kizáró - módon lehet elérni: a tanulók szakképzésbe terelésével, illetve az odakerült tanulók benntartásával. Az utóbbi demográfiai összefüggései kevésbé rajzolódnak ki, ezért csak megemlítjük, hogy az ezzel kapcsolatban megtett intézkedések ellentmondásosak (a Híd programok tapasztalatai, a tankötelezettségi korhatár leszállítása) és erőtlenek voltak. Ennek következménye, hogy a szakmunkásképzésben és a középiskolai szakképzésben ${ }^{4}$ is mind a kimaradó tanulók száma, mind annak a tanulólétszámhoz viszonyított aránya jelentősen megnőtt az évtized során ${ }^{5}$. A szakképzés vonzerejének növelése érdekében hozott intézkedések (például az ösztöndíjak bevezetésével) arra utalnak, hogy a szakpolitika inkább ezt a célt igyekezett támogatni, vagyis az általános iskolai tanulókat mind nagyobb arányban a szakmai képzés két programja irányába terelni, értelemszerűen a gimnáziumi képzés rovására.

$\mathrm{A} z$ állam, amely az évtized során fokozatosan átvette a korábban önkormányzati intézményeket, megteremtve ezzel a rendszerbe való közvetlen beavatkozás, így a képzési kínálat meghatározásának lehetőségét, arra mégsem vállalkozott, hogy a képzési programok keretszámainak lényeges módosításával, vagy valamilyen más közvetlen beavatkozással befolyásolja a továbbtanulás belső arányait. A szakképzés népszerüsítése

3 Lásd például: Széll Kálmán-terv (2011).

4 A képzési programok nevének változása és az ebből adódó keveredés elkerülése miatt használjuk oktatáspolitikai megközelítésben ezeket az elnevezéseket, amennyiben több időszakot átölelő összefüggésben kerülnek említésre.

5 Azon tanköteles koron túli tanulók aránya, akiknek tanulói jogviszonya az előző tanév folyamán „a tanuló mulasztása miatt" megszünt: szakmunkásképzés, 2010: 1,8\%, 2017: 4,8\%, középiskolai szakképzés, 2010: 2,1\%, 2017: 4,6\%. Forrás: Edumap. 
érdekében meghozott intézkedései viszont nem értek célt: a tanulók egyre inkább elfordultak mindkét szakmai képzési programtól. A szakmai középiskola 9. osztályába járó tanulóknak az évfolyamra járó tanulók egészén belüli aránya 2009-től kezdődően folyamatosan csökkent (38,5\%-ról 2017-ig 30,3\%-ra). A szakmunkásképzés 9. osztálya esetében a csökkenés csak 2013-ban kezdődött, de nem kevésbé volt jelentős (31,4\%-ról 24\%-ra esett). Értelemszerüen a gimnáziumi tanulók aránya növekedett meg, ami 2019ben már meghaladta a $42 \%$-ot. $^{6}$

A pályaválasztási irány ilyen erőteljes módosulása arra utal, hogy a lakosság tanulással kapcsolatos igényeinek egyre kevésbé felel meg a 14 éves kori pályaválasztáshoz kötött három alapvető irány. Összetett okai vannak ennek, csak néhány, jól adatolható elemet emelünk ki ezek közül.

- Nemzetközi viszonylatban mind a közép-, mind a felsőfokú végzettség felértékelődik. Mivel a hazai szakmunkásképzés a nemzetközi statisztikákban teljes értékü (felső-) középfokú képzésnek minősül, az ezen a szinten végzettek aránya magas, ugyanakkor a szakmunkásképzés közvetlenül nem vezet a felsőoktatásba, így a felsőoktatás húzóereje a másik két képzési programra (a gimnáziumira és a szakmai középiskolaira) irányul.

- Magyarországon európai viszonylatban alacsony a diplomások aránya (31\%, ami 27 európai ország között a második legalacsonyabb érték ${ }^{7}$ ), de - minden bizonnyal részben ezért - kifejezetten nagy a munkaerőpiaci hozadéka (25 európai ország között a második legmagasabb). A felsőfokú képzésre leginkább hagyományosan a gimnázium készít fel. ${ }^{8}$ A technikumi képzés bevezetése egyszerre könnyíti és nehezíti a diploma elérésének lehetőségét: a szakirányú továbbtanulást segíti, a pályamódosítást viszont gyengíti, így kétséges, hogy a gimnáziumi képzés iránti igényt csökkenteni fogja-e. Különös jelentőséget ad ennek az európai viszonylatban korainak tekinthető program-, szakterület- és szakmaválasztási kényszer.

- A hároméves szakmunkásképzés 2010 körüli ismételt bevezetése annak ellenére, hogy intézményes megoldás segíti az ott végzettek középiskolai tanulmányait, s így az érettségi letételét, a csökkenő közismereti tartalom miatt kevéssé alapozza meg ezt a lehetőséget.

- A szakképzésbe jelentkezők pályamódosítását a 2010 óta bevezetett intézkedések (pl. a szakválasztás korábbi életkorra helyezése, a szakmai képzés elkezdése alacsonyabb évfolyamokon, a közismereti képzés háttérbe szorítása mindkét szakmai képzési programban) egyre inkább ellehetetlenítik, ami - feltételezhetően - szintén a gimnáziumi képzés felé tereli a tanulók egy részét.

- A hazai bér- és munkaügyi adatok arra utalnak, hogy az érettségi lényegesen javítja a munkaerőpiaci esélyeket. 2020-ban az érettségivel nem rendelkező szakmunkások munkanélküliségi rátája 4,3\%, ugyanez szakközépiskolai érettségivel csak 3,5\%. A gimnáziumi végzettség (önmagában) ugyan nem biztosít jó esélyeket (4,2\%), de a felsőoktatásba való bejutás nagyobb esélyét nyújtva szintén kedvező feltételeket teremt

Lásd ezzel kapcsolatban a kötet egy másik tanulmányát (Fehérvári-Hives-Szemerszki 2021).

2019-es adatok. Forrás: Educational at a glance, 2020.

2018-ban a felsőoktatásba belépő magyar hallgatók legalább 69\%-a gimnáziumi érettségivel rendelkezett (a hallgatók további 9\%-ának középfokú végzettségére nincs adat). Forrás: Oktatási Hivatal. 
(a munkanélküliségi ráta föiskolai végzettséggel 3,5\%, egyetemi végzettséggel 1,6\%). ${ }^{9}$ A bérek még az elhelyezkedési esélyeknél is jobban tükrözik az érettségi és a diploma előnyét. A szakmunkásvégzettségűekhez képest a gimnáziumot végzettek bérelőnye 16,6\%, a szakmai középiskolát végzetteké 19,9\%, a főiskolát, illetve egyetemet végzetteké pedig még ennél is lényegesen magasabb: 68 , illetve $130 \%{ }^{10}$

- A középiskolai pályaválasztás előtt álló tanulók szülei mind magasabb iskolai végzettséggel rendelkeznek: a 2010-ben a középfokú pályaválasztásban érdekelt fiatalok jellemzően 40-45 évesre tehető szülei közül 20-25 éves korukban (az 1990-es népszámlálás idején) 40\% rendelkezett középiskolai végzettséggel (érettségivel), tíz évvel később pedig már 51\%. Szociológiai közhely, hogy a szülők legalább a saját iskolai végzettségük elérésére motiválják a gyerekeiket.

\section{Következtetések}

A vizsgálat eredményei szerint az anyai, illetve szülői végzettségi szint összefügg a második gyermek vállalásának tervével (első gyermeket váró anyák és párok körében). A kapcsolat hierarchikus, amennyiben a magasabb képzési szintek esélynövelő tényezőnek mutatkoznak. A felsőfokú végzettség kiemelten valószínüsíti a további gyermekvállalást. A felsőfokú képzésen belül a magasabb szintü végzettség az anya esetében ezt tovább erősíti. Az érettséginél alacsonyabb végzettségű anya, avagy szülőpár kisebb eséllyel tervez ismételten gyermekvállalást. A szülői végzettség és az anya gyermekvállalási tervei között oksági kapcsolatot azonosítottunk. Számos egyéb, a szakirodalom alapján feltételezett hatás - stabilitási, időprés- és halasztási hatások - kontrollálása mellett is szignifikáns a szülői végzettség második gyermek tervezésére gyakorolt önálló hatása.

A képzési rendszer és oktatáspolitikai döntéshozás tekintetében eredményeink több szempontból is figyelemre méltóak lehetnek. Az apák magas szintű végzettségének gyermekvállalási tervekre gyakorolt pozitív hatása ellenére a férfiak jellemzően alacsonyabb képzési szintje és az oktatáspolitikában jelenleg is propagált szakképzés felé irányításuk egyaránt kedvezőtlen demográfiai következményekkel bírhatnak. Az, hogy a szakképzés a magasabb (középfok utáni) képzési szinteken hoz pozitív gyermekvállalási kedvet, alapszinten pedig csökkenti azt, arra utalhat, hogy a szakmát adó képzéseket - gyermekvállalás szempontjából - érdemes lehet a továbblépést biztosító, érettségire épülő képzési rendszerek fejlesztése felé irányítani.

$\mathrm{A} z$, hogy a legalacsonyabb végzettségű anyák és családok esetében magasabb megvalósult termékenységi mutatók ellenére kisebb a gyermekvállalási szándék, jól mutatja a gyermekvállalás tervezettségének különbségeit. A megvalósult termékenység képzési szintek szerinti kétpólusú jellege a tervek esetében a magasabb szintek felé növekvő mintázatot mutat, a direkt képzési hatás azonosítása mentén. Ez az eredmény a termékenységi mutatók növelésére irányuló családtámogatások típusaiban és feltételrendszerében fontos szempont lehet, hiszen miközben ezek a támogatások közvetlenül motiválhatják a tervezett gyermekvállalást, az (egyébként jelentős arányú) nem tervezett gyermekek megszületésére, vállalására inkább közvetetten tudnak hatni (Kapitány-Murinkó 2020).

9 2020-ra vonatkozó adatok. Forrás: KSH-Stadat táblák: 2.1.24.

10 2019-re vonatkozó adatok. Forrás: KSH-Stadat táblák: 2.1.41. 
A képzési rendszert befolyásoló demográfiai folyamatok oldaláról vizsgálva a fenti kérdést jól látható, hogy miközben a jelenlegi oktatáspolitikai szándékok a szakképzés és a szakmai programok népszerüsítése felé hatnak, a gimnáziumi képzés rovására, addig az érettségit adó képzések iránti egyre növekvő igény kikényszeríti a képzési kínálat ehhez történő igazodását. Általánosan tekintve, a magasabb iskolai végzettségre irányuló törekvéseket szociológiai, munkaerőpiaci és az oktatásrendszerbeli folyamatok egyaránt támogatják.

Amennyiben a hazai népesedéspolitika a demográfiai folyamatokra hosszabb távon is hatással lesz, s valóban az iskolázottabb szülők vállalnak a korábbinál több gyereket, az a fenti folyamatokat tovább erősíti. Várható, hogy egyrészt megerősödik a felsőoktatásban való továbbtanulás igénye, de vélhetően nem csak ez fejt ki szívóhatást az érettségit adó képzésekre, mindenekelőtt a gimnáziumi programra, hanem a szakképzés súlypontja is át fog kerülni az érettségi utáni időszakra. A felsőoktatás iránti igény erősödése kapcsán tehát a túlképzési interpretációk és azok cáfolata mellett népesedéspolitikai és oktatáspolitikai szempontokat is érdemes megfontolni. A hozzáférés bővítése, a továbblépés biztosítása, a lemorzsolódás csökkentése adataink szerint növelheti a gyermekvállalási szándékot is.

$\mathrm{A} z$ iskolai végzettség demográfiai folyamatokra gyakorolt hatása összetett, hosszú távon érvényesülő jelenség. Elemzésünk eredményeiből az látszik, hogy a magasabb iskolai végzettség nagyobb esélyt jelent - közvetve vagy közvetlenül, s legalábbis a tervekben a második gyerek megszületésére. Ennek mentén feltételezhető, hogy az iskolázatlanabb rétegek magasabb iskolai végzettséghez juttatása hosszabb távon emelheti a (tervezett) gyerekszámot. E tekintetben ugyanakkor mindenekelőtt az oktatás révén a népesség mint munkaerőforrás növekvő minőségére, az életkörülmények javulására érdemes elsősorban fektetnünk a hangsúlyt.

\section{IRODALOM}

BARtus T. (2017) Az iskolai végzettség és a második gyermekvállalás. Bizonyítékok az Életünk Fordulópontjai adatbázisból. Demográfia, Vol. 60. Nos 2-3. pp. 149-172.

Bartus T., Murinkó L., Szalma I. \& Szél B. (2013) The Effect of Education on Second Births in Hungary: A Test of the Time-squeeze, Self-selection and Partner-effect Hypotheses. Demographic Research, Vol. 28. No. 1. pp. 1-32.

BLAskó Zs. (2009) Családtámogatás, gyermeknevelés, munkavállalás. In: Monostori J., Öri P., S. Molnár E. \& Spéder Zs. (eds) Demográfiai Portré 2009. Jelentés a magyar népesség helyzetéről. KSH Népességtudományi Kutatóintézet, Budapest. pp. 41-53.

Bukodi E. (2001) A házassági homogámia és heterogámia időbeli változása. Statisztikai Szemle, Vol. 79. No. 2.pp. 142-162.

Bukodi E. (2005) Partnerszelekció házasságon belül és kívül. Demográfia, Vol. 48. Nos 2-3. pp. 218-253.

Educational at a glance (2020) https://www.oecd-ilibrary.org/education/education-at-aglance-2020_69096873-en. [Letöltve: 2021.02.17.]

Edumap: https://edumap.oh.gov.hu. [Letöltve: 2021. 02. 16.]

Erát D. (2021) Educational Assortative Mating and the Decline of Hypergamy in 27 European Countries: An Examination of Trends through Cohorts. Demographic Research, Vol. 44. Article 7. pp. 157-188. 
Fehérvári A., Híves T. \& Szemerszki M. (2021) Népesség, szelekció, oktatás. Educatio, Vol. 30. No. 2. pp. 226-241.

GÁвоs A. (2008) Családtámogatási rendszer és a családok helyzete. In: Kolosi T. \& Tótн I. Gy. (eds) Társadalmi riport 2008. Budapest, Tárki. pp. 304-323.

Gábos A., Gál R. I. \& Keller T. (2007) A gyermeknevelés költsége és a társadalmi kompenzáció. TÁRKI Társadalomkutatási Intézet Zrt.

Gáвos A., GÁl R. I. \& Kézdi G. (2009) The Effects of Child-related Benefits and Pensions on Fertility by Birth Order: A Test on Hungarian Data. Population Studies, Vol. 63. No. 3. pp. 215-231.

Harcsa I. \& Monostori J. (2018) A háztartásszerkezet és az iskolai végzettség összefüggései. In: Kolosi T. \& Tó TH I. Gy. (eds) Társadalmi riport 2018. Budapest, Tárki. pp. 109-124.

Husz I. (2006) Iskolázottság és a gyermekvállalás időzítése. Demográfia, Vol. 49. No. 1. pp. 46-67.

KaPITÁNy B. (2018) Bimodális (kétcsúcsú) termékenységi görbe Magyarországon - leíró eredmények és lehetséges okok. Demográfia, Vol. 61. Nos 2-3. pp. 121-146.

Kapitány B. (2020) Bölcsődéztetési tervek Magyarországon. Gyermeknevelés Tudományos Folyóirat, Vol. 8. No. 2.pp. 55-73.

Kapitány B. \& Murinkó L. (2020) Párkapcsolati változások, termékenységi trendek. In: Kolosi T., Szelény I. \& Tóth I. Gy. (eds) Társadalmi riport 2020. Budapest, Tárki. pp. $146-170$.

Kapitány B. \& Spéder Zs. (2018) Gyermekvállalás. In: Monostori J., Öri P. \& Spéder Zs. (eds) Demográfiai portré 2018. KSH NKI, Budapest. pp. 47-64.

KSH-Stadat táblák 2.1.24.: Munkanélküliségi ráta befejezett legmagasabb iskolai végzettség szerint, nemenként (2009-). http://www.ksh.hu/docs/hun/xstadat/xstadat_eves/i_ mef028.html. [Letöltve: 2021. 02.16.]

KSH-Stadat táblák: 2.1.41.: A teljes munkaidőben alkalmazásban állók bruttó átlagkeresete a legmagasabb iskolai végzettség szerint (2019-). http://www.ksh.hu/docs/hun/ xstadat/xstadat_eves/i_qli071.html. [Letöltve: 2021. 02.16.]

KSH Stadat 22.1.1.1.: A népesség, népmozgalom föbb mutatói. https://www.ksh.hu/ stadat_files/nep/hu/nep0001.html. [Letöltve 2020.02. 16.]

Liefbroer, A. C. (2009) Changes in Family Size Intentions across Young Adulthood: A Life-course Perspective. European Journal of Population, Vol. 25. No. 4. pp. 365-386.

MAKAy Zs. (2018) Kisgyermekes anyák munkavállalása és az ezzel kapcsolatos vélemények változása Magyarországon. Magyar Tudomány, Vol. 149. No. 11. pp. 1702-1716.

Makay Zs. \& Blaskó Zs. (2012) Családtámogatás, gyermeknevelés, munkavállalás. In: ÖRI P. \& Spéder Zs. (eds) Demográfiai portré 2012. KSH Népességtudományi Kutatóintézet, Budapest. pp. 45-56.

NéMetr P. (2016) Gyermekvállalási döntések és termékenységi idősorok 1970-től 2011-ig. A gyermekvállalás időzítésének és átlagos szintjének becslése és a gyerekvállalási döntés szimulációs modellje. Doktori értekezés. Budapesti Corvinus Egyetem.

Oktatási Hivatal: 1.3. Az új belépő hallgatók statisztikai száma és megoszlása elővégzettség szerint.https://www.oktatas.hu/felsooktatas/kozerdeku_adatok/felsooktatasi_adatok_ kozzetetele/felsooktatasi_statisztikak/!DARI_FelsooktStat/oh.php?id=letoltes\&param =fir\&query=stat2018_1_3.xlsx. [Letöltve: 2021. 02.17.]

SpÉder Zs. (2001) Gyermekvállalás megváltozott munkaerő-piaci körülmények között. In: Nagy I., Pongrácz T. \& Tóth I. Gy. (eds) Szerepváltozások. Jelentés a nők és férfiak helyzetéről. Budapest, Tárki. pp. 46-64. 
SpÉder Zs. (2006) Mintaváltás közben. A gyermekvállalás időzítése az életútban, különös tekintettel a szülő nők iskolai végzettségére és párkapcsolati státusára. Demográfia, Vol. 49. Nos 2-3. pp. 113-149.

Spéder Zs. (2019) A hazai termékenységi magatartás nemzetközi összehasonlításban. Doktori disszertáció. Budapest. Kézirat.

Spéder Zs. \& Kapitány B. (2007) Gyermekek - vágyak és tények. Dinamikus termékenységi elemzések. Mühelytanulmányok 6. sz. KSH Népességtudományi Kutató Intézet, Budapest.

Spéder Zs. \& Kapitány B. (2009) How Are Time-dependent Childbearing Intentions Realized? Realization, Postponement, Abandonment, Bringing Forward. European Journal of Population, Vol. 25. No. 4. pp. 503-523.

Spéder Zs. \& Kapitány B. (2014) A termékenységi szándékok és a gyermekvállalási gyakorlat kapcsolata. Egy európai összehasonlító vizsgálat tanulságai. Demográfia, Vol. 57. Nos 2-3. pp. 137-181.

Spéder Zs., Murinkó L. \& Oláh L. (2017) Sailing Close to the Wind? The Effects of Third Birth Policies in Post-communist Hungary. Working Papers on Population. Family and Welfare, No. 27. Hungarian Demographic Research Institute, Budapest.

Spéder Zs., Murinkó L. \& Oláh Sz. L. (2019) Cash Support vs. Tax Incentives: The Differential Impact of Policy Interventions on Third Births in Contemporary Hungary. Population Studies, Vol. 74. No. 1. 39-54.

Szabó L., Boros J., Fábián I., Gresits G., Нortobágyi A., Kapitány B., Kis R., Kopcsó K., Leitheiser F., Rohr A., Spéder Zs. \& Veroszta Zs. (2020) Várandós kutatási szakasz. Technikai riport. Kohorsz'18 Magyar Születési Kohorszvizsgálat. Kutatási Jelentések 102. Budapest, KSH Népességtudományi Kutatóintézet.

Széll Kálmán-terv (2011): Összefogás az adósság ellen. http://2010-2014.kormany.hu/ download/4/d1/20000/Sz\%C3\%A911\%20K\%C3\%A1lm\%C3\%A1n\%20Terv.pdf. [Letöltve: 2021.04 .12 .]

TAKÁcs J. (2012) Termékenységi korlátok a 21. század eleji Magyarországon. Demográfia, Vol. 55. Nos 2-3. pp. 147-171.

Veroszta Zs. (2018, ed.) Kutatási koncepció. Kohorsz '18 Magyar Születési Kohorszvizsgálat. Kutatási Jelentések 100. KSH Népességtudományi Kutatóintézet, Budapest.

A cikk a Creative Commons Attribution 4.0 International License (https://creativecommons.org/licenses/ by/4.0/) feltételei szerint publikált Open Access közlemény, melynek szellemében a cikk bármilyen médiumban szabadon felhasználható, megosztható és újraközölhető, feltéve, hogy az eredeti szerző és a közlés helye, illetve a CC License linkje és az esetlegesen végrehajtott módosítások feltüntetésre kerülnek. (SID_1) 